\title{
Colon Leiomyosarcoma
}

National Cancer Institute

\section{Source}

National Cancer Institute. Colon Leiomyosarcoma. NCI Thesaurus. Code C5494.

An aggressive malignant smooth muscle neoplasm that arises from the colon. It is characterized by a proliferation of neoplastic spindle cells. 